\title{
SNOW MELIORATION EFFECT ON WINTER WHEAT YIELDS IN DIFFERENT SOIL AND CLIMATIC ZONES
}

\author{
Petr Tarasenko $^{1}$, Vladimir Tarbaev ${ }^{1}$, Dariya Vasilieva ${ }^{2}$, Maksim Morozov ${ }^{1}$ \\ ${ }^{1}$ Saratov State Agrarian University named after N.I. Vavilov, Russia; \\ ${ }^{2}$ Samara State Technical University, Russia \\ petrvt60@gmail.com, tarbaev1@mail.ru,vasilievadi@mail.ru,jamster777@mail.ru
}

\begin{abstract}
Under conditions of ongoing climate warming and increasing anthropogenic impact on land resources, the use of moisture-saving soil-protecting technologies becomes especially important. Snow cover is of great importance for agriculture, as it changes radiation and thermal balance of underlying surface, protecting soil from cooling and winter crops from freezing, accumulates winter precipitation, being the most important source of increasing soil moisture reserves in arid and subarid zones in spring. Winter precipitation accounts for up to $30 \%$ of the annual norm. Soil moisture reserves formed with their help take up to $42 \%$ in total water consumption for grain crop yield formation during wet summer and up to $75 \%$ during dry summer. This article aims to study the effect of different methods of snow retention and snow cover height on the yield of grain crops. An effective method of snow retention is leaving high stubble after harvesting winter and spring crops. Leaving stubble bushes with a height of $0.35-0.40 \mathrm{~m}$ and a width of $1.5 \mathrm{~m}$ every $4.5 \mathrm{~m}$ provides accumulation of a solid snow cover in steppe areas with a height of $0.30-0.35 \mathrm{~m}$, which increases the yield of wheat. Waders provide a more uniform distribution of snow cover than forest strips. Climate change contributes to the fact that snow retention becomes an urgent problem not only in the dry steppe, but also to the north - even in the forest-steppe. Creation of snow retarders was done on Vetelny state farm, located in Balashovsky district in the western part of Saratov region, in the steppe zone, where chernozem soils prevail in the soil cover. In the autumn period, snow barriers were installed, and in the winter period, their effect on snow accumulation was studied. The study of the effect of snow barriers on soil moisture accumulation during the growing season of winter wheat was compared in the zones of dry steppe, steppe and forest-steppe. It was revealed that during regrowth of winter wheat the least amount of productive moisture stocks in 0-1.0 m soil layer was contained in dry steppe $1377 \mathrm{~m}^{3} \cdot \mathrm{ha}^{-1}$, the highest in forest-steppe zone up to $1841 \mathrm{~m}^{3} \cdot \mathrm{ha}^{-1}$. Snow retention increased the amount of moisture in the soil in the dry steppe, steppe and foreststeppe zone by $251,151,115-131 \mathrm{~m}^{3} \cdot \mathrm{ha}^{-1}$, or $18,10,6-8 \%$, respectively. Thus, rational use of winter precipitation is a significant reserve of agricultural landscape productivity increase, especially in dry-steppe areas.
\end{abstract}

Keywords: agricultural land; moisture-saving technologies; soil conservation technologies; drylands; land resources; crop yields; winter precipitation; snow retention.

\section{Introduction}

In Russia, agriculture is highly dependent on natural and climatic factors, which have a strong influence on the yields and quality of agricultural products.

According to the state report of the Russian Ministry of Natural Resources for 2018, agricultural land in the Russian Federation comprises $22.3 \%$ of the territory (or 382.52 million hectares) and 2.6 hectares of agricultural land per inhabitant of the Russian Federation. There has been a gradual decrease in their area, for example, in 2018 compared to 2017, the area of agricultural land decreased by 0.7 million hectares, and for the period since 2010 - by 10.9 million hectares (or 2.8\%) [1].

Agricultural land is characterized by uneven distribution on the territory of the country. Soils of forest-steppe and steppe zones, occupying more than $12 \%$ of the territory of the country are characterized by the greatest fertility. Lands in these zones are intensively used, the natural vegetation is practically not preserved. Agricultural lands occupy more than $57 \%$ of the area of the forest-steppe zone (including arable land - about $40 \%$ ) and more than $73 \%$ of the steppe zone (including arable land - about 47\%). In some regions of the chernozem zone up to $85-90 \%$ of all lands are ploughed. In the zone of dry steppes (about $1.3 \%$ of the total area of the Russian Federation) agricultural lands occupy more than $85 \%$ of the whole area, on the ploughed area it is lower (about 52\%), pastures are widely spread (about 34\%) [1].

Natural-climatic factors can affect plants in different ways, and some of them (e.g., light and temperature regimes) are virtually unregulated in agriculture, while some (e.g., moisture) can be managed to some extent by humans, which is the basis for the development of irrigated agriculture [2]. The issues of optimizing agricultural landscapes, preserving the quality and quantity of water resources in order to improve the sustainability of rural development attract a lot of attention [3-5]. 
In forest-steppe, steppe, arid-steppe and semi-desert zones insufficient soil moisture by atmospheric precipitation is the main factor that limits the growth, development and productivity of cultivated plants.

With the climate warming currently taking place on the globe, the problems of insufficient atmospheric moisture are increasing. Every year new temperature "records" are set, for example, according to the World Meteorological Organization, 2015 to 2018 were the warmest years since global temperature observations began to be recorded. In the territory of the Russian Federation in 2018 there was warming in all seasons, the rate of which is much higher than the global average. It can be said that the territory of Russia is warming faster than others. According to the state report of the Ministry of Natural Resources of Russia for 2018, the average growth rate of the average annual air temperature in the territory of the Russian Federation from 1876 to 2018 was $0.47^{\circ} \mathrm{C}$ for 10 years, which is 2.5 times higher than the growth rate of global temperature during this period $-0.17-0.18^{\circ} \mathrm{C}$. In 2018 in the Russian Federation there was an increase in the average annual air temperature by $1.58{ }^{\circ} \mathrm{C}$ [1]. Precipitation is unevenly distributed over the seasons of the year, with winter precipitation playing a major role in moisture accumulation in the soil [6]. In arid areas, winter precipitation accounts for up to $30 \%$ of the annual norm. In the southeast of the European part of the country, the amount of snow blown off the fields by winds is on average 50\%. Snow retention provides an increase in grain yield of 35 centners $\cdot \mathrm{ha}^{-1}$ [7].

The study of water reserves in snow, snow retention methods, snow melting and melt water absorption patterns, as well as increase in the crop yields depending on snow retention measures was started in the Volga region back in the early 20th century and has been attracting much attention ever since. It was shown that snow blowing begins at the wind speeds of more than $7 \mathrm{~m} \cdot \mathrm{s}^{-1}$, with $90-95 \%$ of snow being carried at 10-20 cm height [8]. Therefore, increasing the height of plant cuttings dampens the wind flow and contributes to the preservation of winter precipitation.

Annual assessment of anomalies (deviations) of average precipitation in relation to the norm confirms the fact of their uneven distribution over Russia [9]. Climate desertification in the form of separate island territories in the steppe regions of the Russian Federation, in particular in the Volga region and the North Caucasus, is assumed to occur [10].

At present, agriculture in Russia is in a difficult condition against the background of a gradual transition from the old system of farming to more modern methods of agricultural production, with constant competition in the domestic market with foreign agricultural producers. Many previously highly profitable farms have become unprofitable. Anticipated natural and climatic changes, primarily increasing air temperature and the increased demand for water resources, will greatly exacerbate the existing contradictions in the agricultural sector and lead to even greater efforts and energy costs in the production of agricultural products, especially in the zone of insufficient moisture.

Increase in average air temperature increases moisture evaporation, so on territories with insufficient moisture the problem of improving the system of moisture-saving soil reclamation is becoming more and more urgent. The aim of the article is to study the effect of snow melioration on winter wheat yield in different soil and climatic zones of the Middle Volga region and Central Chernozem region.

\section{Materials and methods}

In the Russian Federation, the Volga and Central Federal Districts are characterized by the largest volumes (more than 44\%) of agricultural production. Under the conditions of agricultural land degradation occurring almost everywhere, development and growth of urbanized areas, which is also typical for the territory of the Volga region, the problems of increasing the efficiency of their use become very important $[11 ; 12]$. For a proper agricultural production strategy, especially in areas with insufficient moisture, a well-established regional monitoring of lands and climatic changes is very important.

Identified trends of changes in the main agroclimatic characteristics cause a decrease in productivity of major grain crops and an increase in inter-annual variability of yields. To prevent negative effects of climate change, these trends should be taken into consideration when adjusting technologies of crop cultivation and when selecting species and variety composition of cultivated crops, their correct ratio and rational placement in different soil and climatic zones of the region. 
Four natural zones are distinguished in the Volga region: forest-steppe, arid chernozem steppe, dry steppe with dark-chestnut and chestnut soils and semi-desert steppe with light-chestnut and brown soils. The diversity of soil and climatic conditions of the Volga region is uniquely reflected in the scale of one Saratov region, which territory is crossed by 4 major natural zones: forest-steppe, arid chernozem steppe, dry steppe with dark-chestnut and chestnut soils and semi-desert steppe with light-chestnut soils [13]. Studies were conducted in different natural zones in the Saratov region. Saratov region is located in the southeast of the European part, in the Middle Volga region and belongs to the subboreal (moderately warm) belt. Significant differences in soil and climatic conditions and geomorphological conditions are observed in the region, especially between the right-bank and left-bank districts. In different districts of the region there is an average rainfall of 200 to $500 \mathrm{~mm}$. In the right bank the amount of precipitation is $400-550 \mathrm{~mm}$, in the left bank it is $300-350 \mathrm{~mm}$, in the extreme south-east it is $250 \mathrm{~mm}$. In addition, for comparison, materials obtained by one of the authors were used to study the snow retention effect on the yield of winter wheat in the forest-steppe zone in the Tambov and Penza regions [14].

According to N.I. Fedorov [13], in Saratov region the arrival of photosynthetically active radiation ( 2.5 billion $\mathrm{kcal} \cdot \mathrm{ha}^{-1}$ ) does not limit the productivity of one of the main crops of spring wheat and is quite sufficient to create $16 \mathrm{t} \cdot \mathrm{ha}^{-1}$ of dry mass. In his opinion, unfavorable temperature regime, especially in the left bank areas of the region, for the growth and productivity of spring wheat is much more often than favorable. To a greater extent, the temperature regime is reflected in the initial and final phenophases, to a lesser extent - in the intermediate ones.

Snow cover is of high importance for agriculture, as it changes radiation and thermal balance of the underlying surface, protecting soil from cooling and winter crops from freezing, accumulates winter precipitation, being the most important source of increasing soil moisture reserves in spring. Winter precipitation accounts for up to $30 \%$ of the annual norm. Soil moisture reserves formed with their help occupy up to $42 \%$ in the total water consumption for grain crop yield formation during wet summers and up to $75 \%$ during dry summers [14]. Therefore, loss (up to 50\%) of water resources in winter for farms is a lost profit (up to 3-5 centners. ha ${ }^{-1}$ of grain) [13].

In winter, during snowstorms, snow begins to move at the wind speed of $2.5-3.0 \mathrm{~m} \cdot \mathrm{s}^{-1}$. At the speed of 7-8 $\mathrm{m} \cdot \mathrm{s}^{-1}$, up to $90-95 \%$ of snow is blown away and transported at the height of 0.1-0.2 m. Creation of barriers in the fields located across the direction of prevailing winds contributes to significant snow retention (Fig. 1).
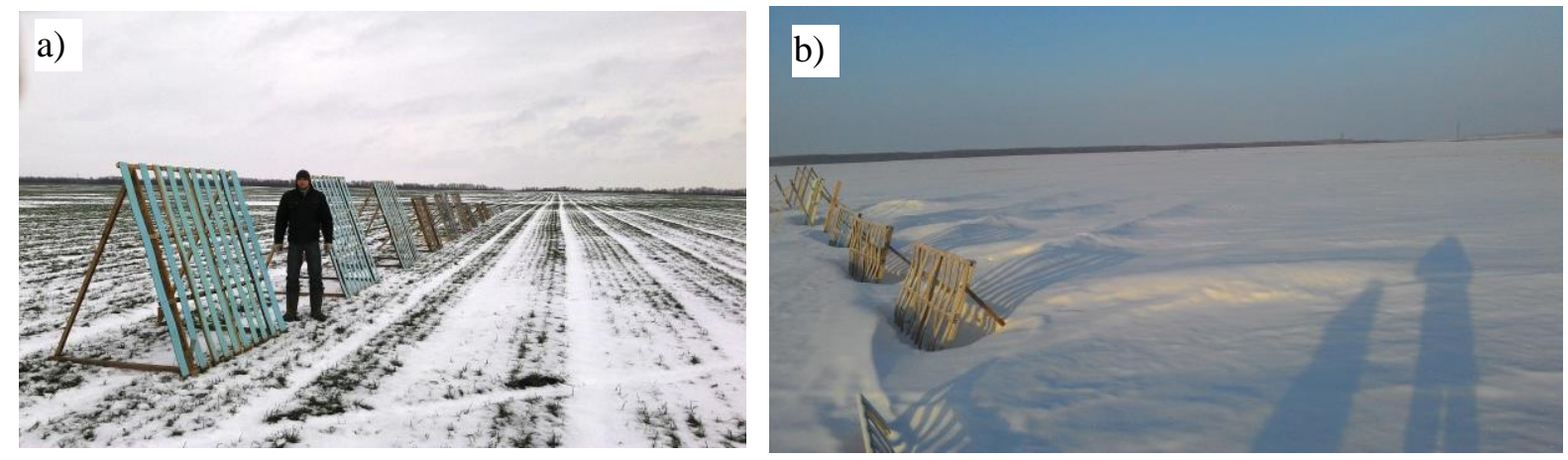

Fig. 1. Impact of barriers on snow retention in Saratov region:

1 - barriers in the fall; 2 - result of snow retention in winter) (Photo by M. Morozov)

Creation of these snow-retarding devices was carried out on the territory of the state farm Vetelny, located in Balashovsky district in the western part of Saratov region. The territory belongs to the steppe zone, where chernozem soils prevail in the soil cover. In the autumn period, snow barriers were installed, and in the winter period their effect on snow accumulation was studied. It was found that snow retarders contribute to a significant increase in the height of the snow cover, which is shown in the photos.

Obstacles in the form of snow rolls, sledge stubble, stubble and sowable mounds delay and preserve snow on the fields $[15,16]$. Therefore, snow retention with the help of stubble is of great importance. Leaving high stubble after harvesting winter and spring crops is quite an effective method of snow retention. Previously the measurements of snow in Saratov region, in the field with uncut sunflowers 
(because of drought in 2009), showed that stalks of this crop with a height of 0.75-0.88 $\mathrm{m}$, left in winter, retained up to $0.25 \mathrm{~m}$ of snow or up to $63 \mathrm{~mm}$ of moisture (Fig. 2).

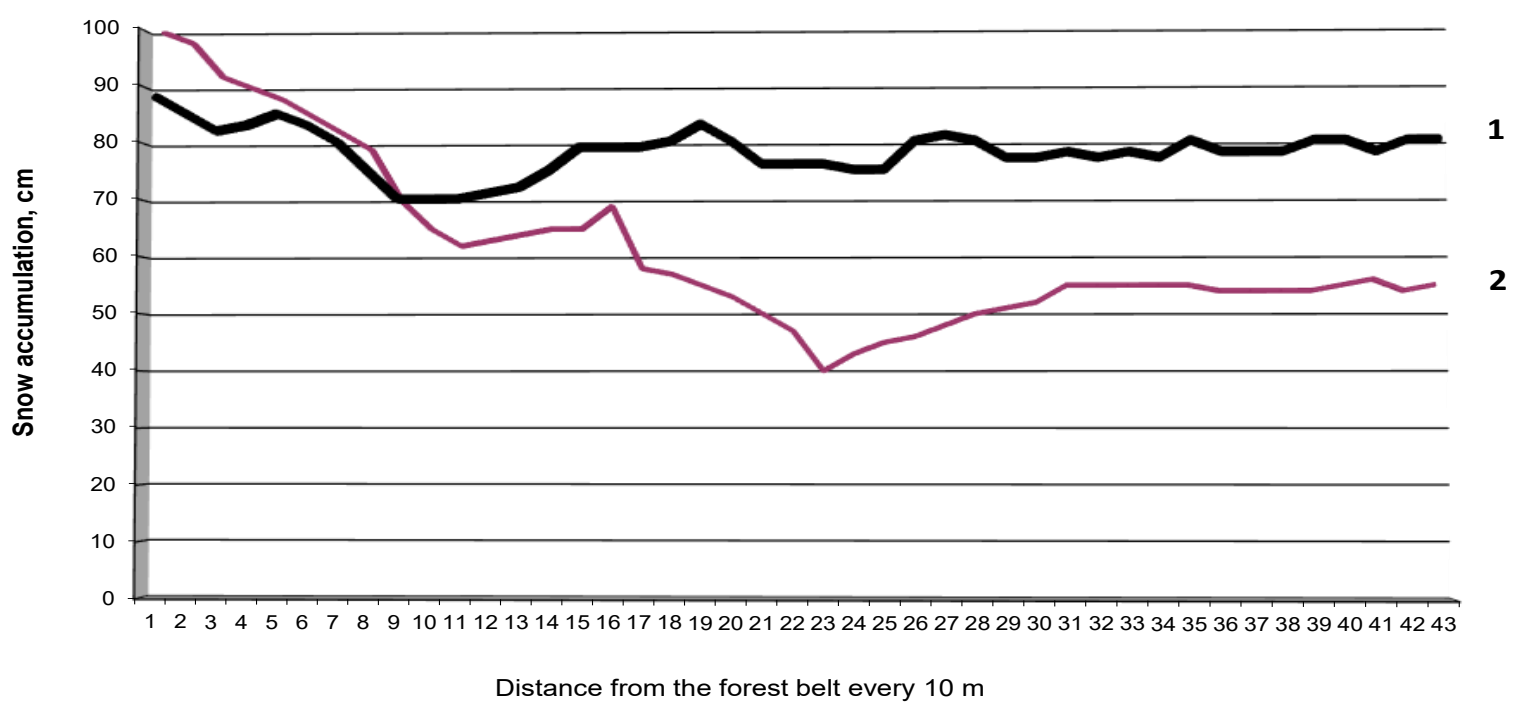

Fig. 2. Influence of uncut sunflower plants on snow retention in Saratov district:

1 - sunflower; 2 - control

Currently, there are studies on snow retention with the help of stubble and sowing coulters. On their basis, there are recommendations for formation of the necessary distance between different sods depending on their height. Due to this, it is possible to affect the value of snow accumulation (from 0.07 to $0.25 \mathrm{~m}$ ) [15; 16]. For example, leaving, at separate harvesting of stubble bushes of the height 0.35-0.40 m, width $1.5 \mathrm{~m}$ every $4.5 \mathrm{~m}$ provides accumulation of a continuous snow cover in steppe areas of the height $0.30-0.35 \mathrm{~m}$. The yield of spring wheat on the treatments where stubble bushes were left, reached 14 centners, and on the treatments with ordinary stubble without snow retention -12.2 centners per ha [17].

The use of high-stem plants (mustard, sunflower, etc.) is recommended with a distance of 7 to $14 \mathrm{~m}$. According to the data of Chirkov [18], the best result in snow retention is observed when using mustard $(0.38 \mathrm{~m})$, sunflower $(0.24 \mathrm{~m})$ and stubble $(0.14 \mathrm{~m})$ shrubs.

It should be noted that there is a correlation between optimization of the snow cover thickness under climate change conditions and the soil water regime, and the crop yields of cultivated crops in different soil and climatic conditions. Certain questions on the relevance of snow retention are raised in the black earth-steppe and forest-steppe zone.

\section{Results and discussion}

We know that optimal moisture availability of chernozems improves their fertility and increases crop yields. Conversely, oversaturation of soils with melt water worsens their thermal, nutrient regime (due to nitrate leaching), which will reduce crop production. Climate change encourages farmers to carry out snow retention in the forest-steppe. For example, the Pugachevskoe agricultural enterprise [19] in Penza area leaves a high stubble for snow retention after harvesting grain crops.

The effect of additional snow deposition (in\% relative to the natural background) on the productivity of winter wheat in different soil and climatic zones was studied (Table 1).

The data show that the effect of additional snow deposition on winter wheat productivity was most pronounced in the dry steppe agro-landscapes.

It was found that during winter wheat regrowth the least amount of productive moisture reserves in the $0-1.0 \mathrm{~m}$ soil layer was found in the dry steppe $1377 \mathrm{~m}^{3} \cdot \mathrm{ha}^{-1}$, the highest in the forest-steppe zone up to $1841 \mathrm{~m}^{3} \cdot \mathrm{ha}^{-1}$. Snow retention increased the amount of moisture in the soil in the dry steppe, steppe and forest-steppe zone by $251,151,115-131 \mathrm{~m}^{3} \cdot \mathrm{ha}^{-1}$, or $18,10,6-8 \%$, respectively. 
In dry steppe against the background of snow retention, winter wheat plants were better provided with water resources during the growing season. Compared to the control their water consumption from 0-1.0 m layer was $229 \mathrm{~m}^{3} \cdot \mathrm{ha}^{-1}$ or $19 \%$ higher.

Table 1

Additional snow deposition effect on winter wheat productivity indicators

\begin{tabular}{|c|c|c|c|c|c|}
\hline $\begin{array}{c}\text { Additional snow } \\
\text { deposition }\end{array}$ & $\begin{array}{c}\text { Plant } \\
\text { height, } \\
\text { m }\end{array}$ & $\begin{array}{c}\text { Weight of } \\
\text { plants, } \\
\mathbf{g} \cdot \mathbf{m}^{-2}\end{array}$ & $\begin{array}{c}\text { Number of } \\
\text { grains per } \\
\text { ear, pcs. }\end{array}$ & $\begin{array}{c}\text { Weight of 1000 } \\
\text { grains, g }\end{array}$ & $\begin{array}{c}\text { Biological } \\
\text { yield, } \mathbf{g}^{-2} \mathbf{m}^{-2}\end{array}$ \\
\hline \multicolumn{7}{|c|}{ Saratov region, left bank dry steppe } \\
\hline 0 & 0.606 & 608 & 14.3 & 33.6 & 237.3 \\
\hline 30 & 0.643 & 629 & 16.9 & 34.3 & 252.4 \\
\hline 60 & 0.646 & 774 & 16.2 & 35.2 & 298.8 \\
\hline 100 & 0.700 & 828 & 15.1 & 35.0 & 354.6 \\
\hline \multicolumn{7}{|c|}{ Saratov region, right-bank chernozem steppe } \\
\hline 0 & 0.735 & 769 & 17.1 & 39.7 & 284.1 \\
\hline 30 & 0.761 & 945 & 18.7 & 41.2 & 331.2 \\
\hline 60 & 0.778 & 962 & 20.0 & 40.9 & 357.8 \\
\hline 100 & 0.801 & 1017 & 22.7 & 42.7 & 393.6 \\
\hline \multicolumn{7}{|c|}{ Saratov region, forest-steppe } \\
\hline 0 & 0.858 & 909 & 23.3 & 37.8 & 382.0 \\
\hline 30 & 0.888 & 997 & 23.0 & 40.0 & 404.8 \\
\hline 60 & 0.900 & 1082 & 23.8 & 40.3 & 439.9 \\
\hline 100 & 0.908 & 1072 & 26.6 & 39.1 & 435.5 \\
\hline \multicolumn{7}{|c|}{ Tambov, Penza region, forest-steppe } \\
\hline 0 & 0.935 & 1309 & 22.4 & 41.9 & 559.8 \\
\hline 30 & 0.998 & 1536 & 23.8 & 43.7 & 642.7 \\
\hline 60 & 1.045 & 1558 & 23.4 & 44.0 & 636.1 \\
\hline 100 & 0.991 & 1242 & 23.4 & 41.4 & 506.8 \\
\hline
\end{tabular}

Relative to dry steppe in the chernozem-steppe zone, the effect of snow retention decreased by 2 times. In the arid zone, water consumption by winter wheat from $0-1.0 \mathrm{~m}$ soil layer against the background of additional snow deposition in the chernozem steppe exceeded the control by only $111 \mathrm{~m}^{3} \cdot \mathrm{ha}^{-1}$, or by $7.8 \%$.

The least effect of snow accumulation was noted in the forest-steppe zone. The difference in water consumption of winter wheat from one-meter soil layer against snow accumulation was $78-90 \mathrm{~m}^{3} \cdot \mathrm{ha}^{-1}$ or $4.7-5.0 \%$.

Analysis of the biological yield of winter wheat, total moisture consumption from 0-1.0 $\mathrm{m}$ soil layer and effective precipitation in arid, subarid zones revealed their close relationship, which can be expressed by equation (1):

$$
y=0.0001 x^{2}+0.0108 x+11.352\left(\eta=0.89 ; t_{\eta}=5.05>t_{m}=2.45\right),
$$

where $x$ - total moisture consumption from $0-1.0 \mathrm{~m}$ soil layer + effective precipitation, $\mathrm{m}^{3} \cdot \mathrm{ha}^{-1}$;

$y$ - grain yield, $\mathrm{g} \cdot \mathrm{m}^{-2}$.

According to the analysis above, we can confidently say that the rational use of winter precipitation is a significant reserve for improving the productivity of agricultural landscapes, especially in the drysteppe areas.

Thus, the studies of different moisture conservation methods in spring wheat crops in the dry steppe have confirmed the assumption about natural moisture reserves and the possibility of their effective use. When comparing snow retention with the help of bushes and forest strips, it should be noted that forest strips do not provide uniform snow accumulation. A significant part of snow is deposited in the strips themselves and in the immediate vicinity of them. In the middle of the interstrip space the height of snow cover is insignificantly higher than that of unprotected fields. The waders provide a more uniform 
distribution of snow cover [7;8]. It should be noted that there is a correlation between optimization of the snow cover thickness under climate change conditions and the water regime of the soil, and the yield of cultivated crops in different soil and climatic conditions. Snow accumulation has the greatest effect in the dry-steppe and steppe zones, which is confirmed by studies [14;20]. Certain questions about the relevance of snow accumulation arise in the black earth-steppe and forest-steppe zones.

\section{Conclusions}

1. Biological yield of winter wheat is closely connected with the total moisture consumption from 0-1.0 $\mathrm{m}$ soil layer and effective precipitation in arid and subarid zones.

2. Effective methods of snow retention (for example, leaving high stubble after harvesting winter and spring crops, creation of artificial barriers, etc.) contribute to preservation of continuous snow cover in steppe areas and are the reserve for increasing the productivity of agricultural landscapes.

\section{References}

[1] Государственный доклад «О состоянии и об охране окружающей среды Российской Федерации в 2018 году». М.: Минприроды России; НПП «Кадастр», 2019. 844 с. [online] [21.03.2021] Available at: https://www.mnr.gov.ru/docs/gosudarstvennye_doklady/

[2] Zhou X., Zhang Y., Sheng Z., Manevski K., Andersen M.N., Han S., Li, Yang Y. Did water-saving irrigation protect water resources over the past 40 years? A global analysis based on water accounting framework, Agricultural Water Management, Volume 249, 2021, 106793, DOI: 10.1016/j.agwat.2021.106793.

[3] Kędziora A., Negussie Y. Z., Asres M. T., Zalewski M.J. Shaping of an agricultural landscape to increase water and nutrient retention, Ecohydrology \& Hydrobiology, Volume 11, Issues 3-4, 2011, pp. 205-222, DOI: 10.2478/v10104-011-0048-x.

[4] Chen L., Chen Z., Jia G., Zhou J., Zhao J., Zhang Z. Influences of forest cover on soil freeze-thaw dynamics and greenhouse gas emissions through the regulation of snow regimes: A comparison study of the farmland and forest plantation, Science of The Total Environment, Volume 726, 2020, 138403, DOI: 10.1016/j.scitotenv.2020.138403.

[5] Yan Y., Yan R., Wang X., Xu X., Xu D., Jin D., Chen J., Xin X. Grazing affects snow accumulation and subsequent spring soil water by removing vegetation in a temperate grassland, Science of The Total Environment, Volume 697, 2019, 134189, DOI: 10.1016/j.scitotenv.2019.134189.

[6] Seibert J., Jenicek M., Huss M., Ewen T., Viviroli D. Chapter 4 - Snow and ice in the hydrosphere, Editor(s): Wilfried Haeberli, Colin Whiteman, Snow and Ice-Related Hazards, Risks, and Disasters (Second Edition), Elsevier, 2021, Pages 93-135, DOI: 10.1016/B978-0-12-817129-5.00010-X.

[7] Бараев А.И. Яровая пшеница (Spring wheat). Moscow, Kolos: М. Колос, 1978, 429 p. (In Russian).

[8] Азаров Н. К. Дифференцировать накопление снега на полях (Differentiate between snow accumulation in the fields) Agriculture: Земледелие, 1992, No 1. pp. 35-37.

[9] Аномалии осадков (Precipitation anomalies.). Russian Statistical Yearbook: Российский статистический ежегодник, 2006, 806 p. (In Russian).

[10] Парфенова Е.И., Чебакова Н.М. Возможное климатическое опустынивание островных степей в Южной Сибири и защитное лесоразведение (Possible climatic desertification of island steppes in southern Siberia and protective afforestation). Land improvement and water management: Мелиорация и водное хозяйство, 2005, № 1, pp. 16-18. (In Russian).

[11] Kondolskaya A., Vasilieva D., Parsova V., Antropov D. Problems of conservation and use of agricultural land in urban agglomerations. Engineering for Rural Development. 2019. C. 774-779. DOI: 10.22616/ERDev2019.18.N108

[12] Khasaev G., Vlasov A., Vasilieva D., Parsova V. Trends of development of agrolandscapes in samara region as result of land reform. Engineering for Rural Development. Proceedings. 2018. C. 630-634. DOI: 10.22616/ERDev2018.17.N244

[13] Федоров, Н. И. Продуктивность пшеницы (Wheat productivity). Saratov: Саратов, 1980, 176 p. (In Russian).

[14] Тарасенко П.В. Система влагосберегающих почвозащитных мелиораций в Среднем Поволжье и Центральном Черноземье (System of water-saving soil conservation reclamation in 
the Middle Volga and Central Black Earth regions). Author's abstract of the dissertation Doctor of Agricultural Sciences: Автореферат диссертации доктора сельскохозяйственных наук. Saratov State Agrarian University named after N.I. Vavilov: Сарат. гос. аграр. ун-т им. Н.И. Вавилова. Saratov: Саратов, 2014. 41 p. (In Russian).

[15] Курдюков Ю.Ф. Пути регулирования экологического состояния почвы в агроценозе (Ways to regulate the ecological state of the soil in an agrocenosis). Problems and ways of overcoming drought in the Volga region: collection of scientific works. Saratov: Проблемы и пути преодоления засухи в Поволжье: сб. науч. тр. Саратов, 2000, 2 Part, pp. 95-121. (In Russian).

[16]Кряжков В.М., Жук А.Ф., Спирин А.П. Технические проблемы влагосбережения в земледелии (Technical problems of moisture conservation in agriculture). Agriculture: Земледелие, 1990, № 1. pp. 46-56. (In Russian).

[17]Соколов Н.M. Обоснование параметров гребнестерневых кулис, образуемых почвообрабатывающим орудием ОП-3С (Justification of the parameters of the ridges formed by the OP-3S tillage tool). Bulletin of Saratov State Agrarian University named after N.I. Vavilov: Вестник Саратовского госагроуниверситета им. Н.И. Вавилова, 2010, № 11, pp. 59-62. (In Russian).

[18] Чирков Ю.И. Агрометеорология (Agrometeorology). Leningrad. Hydrometeoisdat: Л. Гидрометеоиздат, 1986. 362 p. (In Russian).

[19] Шугуров А.И. Технология больших возможностей (Technology for great opportunities). Penza, 2003. 37 p. (In Russian).

[20] Бакаев Н. М. Правильно вести снегозадержание (Correctly manage snow-making) Agriculture: Земледелие, 1983, No 12. pp. 22-23. (In Russian). 